\title{
THE SUPREME COURT'S NEW LABOUR TRILOGY Momentous Decisions and a Modest Critique
}

\section{Craig Neuman, $Q^{*}$}

\section{Introduction}

Early in 2015 the Supreme Court of Canada pronounced judgment in three cases where the constitutional protection of freedom of association in section 2(d) of the Canadian Charter of Rights and Freedoms was invoked to challenge different labour legislation. ${ }^{1}$ Judgments in Mounted Police Association of Ontario $v$ Canada $(A G)^{2}$ and Meredith $v$ Canada $(A G)^{3}$ were pronounced together on January 16, 2015. The decision in Saskatchewan Federation of Labour $v$ Saskatchewan $n^{4}$ came out two weeks later, on January 30th. The decisions, in particular the SFL decision, portend "striking" changes for labour relations law in Canada.

This trio of cases recalls another occasion, 28 years ago, when the Supreme Court examined freedom of association in a labour relations context in three companion rulings: Reference Re Public Service Employee Relations Act (Alberta ) Public Service Alliance of Canada v Canada ${ }^{6}$; and Retail, Wholesale and Department Store Union v Saskatchewan. ${ }^{7}$ This old labour trilogy has now been supplanted by a new labour trilogy. Whatever might be said about the logic of the progression of the Court's thinking on this topic, it displays, at least, a certain symmetry.

In this paper, with a nod to the expositive force of organizing thoughts in triads, I offer three criticisms of the Supreme Court's recent work re-shaping what the constitutional protection of freedom of association means in the field of labour relations law: (1) it ignores the reasonably clear intent of the drafters of the Charter; (2) it has been inconsistent and unpredictable, producing destabilizing effects; and, (3) it usurps to the judiciary a role in regulating labour relations that is better left to legislators.

\section{The old labour trilogy - A brief history}

First, some context may be helpful for those less familiar with the Supreme Court's body of work in this area.

In 1987, five years after the Charter became part of our constitutional law, the Supreme Court of Canada pronounced its judgments in the original labour trilogy. One of the decisions arose from a constitutional reference that the Alberta Government initiated to determine the validity of public sector labour legislation that prohibited strikes and lockouts and established compulsory arbitration as the means to conclude collective agreements when public employers and unions could not arrive at negotiated contract settlements. The other two cases involved actions by unions seeking declarations to invalidate a federal wage restraint law of the day (simi- 
lar to the legislation upheld in Meredith) and legislation that had temporarily prohibited a strike and corresponding lockout from starting in the dairy industry in Saskatchewan. The Supreme Court used these cases as an early occasion for it to address the scope of freedom of association in section 2(d) of the Charter generally, and more specifically its application to government regulation of collective labour relations.

Labour relations cases have enjoyed a nearmonopoly of attention in freedom of association jurisprudence in this country ever since.

In the original trilogy a six-two majority of the Court (with then Chief Justice Dickson in dissent on the principal issue, but not in the result in all of the cases) held that freedom of association did not encompass constitutional protection of a right to collective bargaining or a right to strike.

This view of freedom of association in the original labour trilogy remained more or less intact for 20 years. Then in 2007 the Supreme Court of Canada issued its decision in Health Services and Support -- Facilities Subsector Bargaining Assn v British Columbia. ${ }^{8}$ It overruled the conclusion in the 1987 Alberta Reference and companion cases, at least to the extent of recognizing a constitutional right, flowing from section 2(d) of the Charter, for associations of individuals in the labour relations sphere of activity to have access to a meaningful process of collective bargaining to pursue their workplace aspirations. The Court stopped short of recognizing constitutionally enshrined status for any particular process or model of collective bargaining, or for any particular bargaining dispute resolution mechanism. In Health Services the Court declined to say whether or not a freedom to strike was included within its new conception of freedom of association.

The next significant step in the evolution of the Court's jurisprudence was in 2011, when it ruled in the case of Ontario (AG) $v$ Fraser. ${ }^{9}$ The Justices examined the constitutionality of the Ontario government's legislative response to an earlier Supreme Court ruling, which had found the complete exclusion of agricultural workers from a statutory labour relations regimen wanting, because it denied them opportunity to associate to pursue workplace goals. ${ }^{10}$ The legislative answer to the deficiency identified in Dunmore, which the Supreme Court endorsed in Fraser, was the palest imitation of a conventional labour relations statute: it did not allow for unions to be certified as bargaining agents; it did not include a method to resolve bargaining disputes; and it did not contemplate a right to strike. It said associations of employees could make representations to employers, which employers had to acknowledge receiving. The act said nothing about employers having to respond substantively to representations, or to negotiate with employee associations. A majority of judges inferred that a "duty to bargain in good faith" was intended by the legislation, but a labour relations practitioner would not recognize the process by that label.

There was a strongly-worded dissent in Fraser calling Health Services a mistake, and advocating for the Court to overrule it. ${ }^{11}$ Even the majority, in following Health Services, by nonetheless upholding the particular piece of legislation that was before it, seemed to significantly curtail what Health Services should be understood to have said about the scope of the constitutional freedom in this labour relations context.

Fraser was widely viewed as signalling the Supreme Court's retreat from more expansive views of freedom of association protections in the labour relations field that were reflected in some of the jurisprudence emanating from lower courts after Health Services. Many perceived the ruling to indicate that a less interventionist approach on constitutional grounds would be taken with labour relations laws in the future.

All this made the next major pronouncements from the Supreme Court at the beginning of 2015, in the new labour trilogy, that much more surprising.

\section{The new trilogy}

In MPAO, the Court struck down federal legislation that excluded RCMP officers from a broader public sector labour relations statutory scheme 
that included prominent roles for employee associations, in the form of unions, to exist and function. Instead, legislation specific to the national police force substituted a program for employee input through staff representatives not chosen by employees, who were also found to lack independence from RCMP management.

The majority in MPAO found employee choice in appointing representatives, and autonomy of those chosen representatives, to be crucial in affording employees freedom of association in the workplace. In the joint reasons of Chief Justice McLachlin and Justice LeBel they expressed it thus:

81 We have concluded that s. 2(d) protects the right of employees to associate for the purpose of meaningfully pursuing collective workplace goals. The government therefore cannot enact laws or impose a labour relations process that substantially interferes with that right. This raises the question - what are the features essential to a meaningful process of collective bargaining under s. 2(d)? ... we conclude that a meaningful process of collective bargaining is a process that provides employees with a degree of choice and independence sufficient to enable them to determine their collective interests and meaningfully pursue them.

82 Collective bargaining constitutes a fundamental aspect of Canadian society which 'enhances the human dignity, liberty and autonomy of workers by giving them the opportunity to influence the establishment of workplace rules and thereby gain some control over a major aspect of their lives, namely their work' (Health Services, at para. 82). Put simply, its purpose is to preserve collective employee autonomy against the superior power of management and to maintain equilibrium between the parties. This equilibrium is embodied in the degree of choice and independence afforded to the employees in the labour relations process.

83 But choice and independence are not absolute: they are limited by the context of collective bargaining. In our view, the degree of choice required by the Charter for collective bargaining purposes is one that enables employees to have effective input into the selection of the collective goals to be advanced by their association. In the same vein, the degree of independence required by the Charter for collective bargaining purposes is one that ensures that the activities of the association are aligned with the interests of its members. ${ }^{12}$

It seems to me that the majority of the Court was on firmer, more familiar ground in $M P A O$ when giving effect to section 2(d) of the Charter. They were addressing the impact of legislation on the freedom of individuals to form an association to speak and act for them in a particular setting, as opposed to addressing what activities, at a constitutional minimum, the association ought to be free to engage in to achieve its collective aims (for example, to require an employer to bargain with them, or to strike if dissatisfied with an employer's offer). To the extent the reasoning in $M P A O$ focused on the need for laws to respect constitutive attributes of associations, it can be seen to align more comfortably with the reasoning adopted in earlier decisions of the Court, like Dunmore, and even with the predominant approach taken to describe the basic nature of the constitutional freedom in the original labour trilogy.

In Meredith, the Court upheld federal wage restraint legislation that dictated pay increases for RCMP officers (and imposed limits on pay increases across the unionized and non-union federal public service). The majority reasoned:

25 Section 2(d) guarantees a right to a meaningful labour relations process, but it does not guarantee a particular outcome. What is guaranteed is the right of employees to associate in a meaningful way in the pursuit of collective workplace goals ...

26 For the affected RCMP members, the $E R A$ [wage restraint legislation] resulted in a rollback of scheduled wage increases from the previous Pay Council recommendations accepted by the Treasury Board, from between $2 \%$ and $3.5 \%$ to $1.5 \%$ in each of 2008,2009 and 2010. The original increase would also have doubled service pay and increased the Field Trainer Allowance. Both of these were also eliminated by the $E R A$, subject to subsequent negotiations pursuant to s. 62 of that Act. 
27 The Attorney General of Canada acknowledges that wages are an important issue, but notes that the limits imposed by the $E R A$ were time-limited in nature, were shared by all public servants, and did not permanently remove the subject of wages from collective bargaining. Accordingly, he suggests that the importance of the wage restraints does not rise to the level of a s. 2(d) violation. For the reasons that follow, we conclude that s. 2(d) was not breached.

28 The facts of Health Services should not be understood as a minimum threshold for finding a breach of s. 2(d). Nonetheless, the comparison between the impugned legislation in that case and the ERA is instructive. The Health and Social Services Delivery Improvement Act, S.B.C. 2002, c. 2, Part 2, introduced radical changes to significant terms covered by collective agreements previously concluded. By contrast, the level at which the ERA capped wage increases for members of the RCMP was consistent with the going rate reached in agreements concluded with other bargaining agents inside and outside of the core public administration and so reflected an outcome consistent with actual bargaining processes. The process followed to impose the wage restraints thus did not disregard the substance of the former procedure. And the $E R A$ did not preclude consultation on other compensation-related issues, either in the past or the future.

30 Simply put, the Pay Council continued to afford RCMP members a process for consultation on compensation-related issues within the constitutionally inadequate labour relations framework that was then in place. The $E R A$ and the government's course of conduct cannot be said to have substantially impaired the collective pursuit of the workplace goals of RCMP members. ${ }^{13}$

In the result, Meredith mimicked what the Supreme Court did when it upheld federal wage restraint legislation back in 1987 in one of the original labour trilogy cases. ${ }^{14}$ The reasoning in Meredith was different, to be sure, but the outcome was the same. This is but one of the puzzling aspects of the Court's evolving decisions applying section 2(d) of the Charter in the labour relations arena.

To complete the new labour trilogy, in SFL the Supreme Court invalidated provincial legislation in Saskatchewan that allowed the government and public employers to designate public servants to be providing essential services, which precluded them from participating in strike action when undertaken by other public sector workers. A majority found that this essential services legislation (variations of which have existed for many years in many provinces, and at the federal level) unduly interfered with the constitutionally guaranteed access of employees to a meaningful collective bargaining process. Important factors the Court identified in arriving at this conclusion in respect of the Saskatchewan statute was that it failed, in the Court's eyes, to provide for sufficiently robust tribunal oversight of essential services designations that public employers, in the absence of union agreement, were empowered to make, or for an alternative bargaining dispute resolution model that employees could access instead of striking, like compulsory arbitration of contract terms. ${ }^{15}$

The truly "momentous" feature of the SFL decision that I allude to in the title of this paper is that the Supreme Court chose the occasion to unequivocally introduce a constitutional "right to strike" into section 2(d) of our Charter of Rights and Freedoms. Justice Abella, writing for the majority, said, as part of a stirring introduction:

2 The question in this appeal is whether a prohibition on designated employees participating in strike action for the purpose of negotiating the terms and conditions of their employment amounts to a substantial interference with their right to a meaningful process of collective bargaining and, as a result, violates s. 2(d) of the Charter....

3 The conclusion that the right to strike is an essential part of a meaningful collective bargaining process in our system of labour relations is supported by history, by jurisprudence, and by Canada's international obligations. As Otto Kahn-Freund and Bob Hepple recognized: 
The power to withdraw their labour is for the workers what for management is its power to shut down production, to switch it to different purposes, to transfer it to different places. A legal system which suppresses the freedom to strike puts the workers at the mercy of their employers. This - in all its simplicity - is the essence of the matter.

(Laws Against Strikes (1972), at p. 8)

The right to strike is not merely derivative of collective bargaining, it is an indispensable component of that right. It seems to me to be the time to give this conclusion constitutional benediction. ${ }^{16}$

It is difficult to overstate the significance of SFL. With respect, I think the decision is wrong. Following are three reasons why I think that.

\section{Legislative intent}

Section 2(d) of the Charter confers "freedom of association" on "[e]veryone". The words in the statute (and not to ignore its elevated stature as a constitutional document, but it is still a statute) are undeniably broad, but also few, and simple. The provision speaks of a freedom to associate, not a freedom to act in association. The constitutional guarantee is precisely described: individuals are free to get together -- to coalesce in groups -- with other individuals. What those groups of individuals can or cannot then do, under the law, seems a matter quite apart from what section 2(d) concerns itself with. It speaks, on its face, to protecting acts of associating, not the acts of associations.

There is no indication in the language of section 2(d) that it was conceived with a particular purpose in mind of enshrining activities of associations of employees in the labour relations context. It would not be apparent to a reader of the Charter, at first glance, that concepts like union certification, collective bargaining and strikes were being entrenched in our nation's foundational, constating legal arrangements, alongside freedom of speech, religion and peaceful assembly.
The legislative context in which the Charter was enacted in 1982 only serves to reinforce an appreciation that the framers of our modern constitutional arrangements likely did not intend the words they chose for section 2(d) to imbue collective bargaining, strike action and other labour relations activities with a constitutional aura. Justice McIntyre made the following observation about legislative context at 412-13 of his concurring judgment in the Alberta Reference case, at the time of the original labour trilogy in 1987, when that context would still have been fresh in mind:

Labour relations and the development of the body of law which has grown up around that subject have been for many years one of the major preoccupations of legislators, economic and social writers, and the general public. Strikes are commonplace in Canada and have been for many years. The framers of the Constitution must be presumed to have been aware of these facts. Indeed, questions of collective bargaining and a right to strike were discussed in the Minutes of Proceedings and Evidence of the Special Joint Committee of the Senate and of the House of Commons on the Constitution of Canada (Issue No. 43, pp. 6879 , January 22, 1981). It is apparent from the deliberations of the Committee that the right to strike was understood to be separate and distinct from the right to bargain collectively. And, while a resolution was proposed for the inclusion of a specific right to bargain collectively, no resolution was proposed for the inclusion of the right to strike. This affords strong support for the proposition that the inclusion of a right to strike was not intended. ${ }^{17}$

And there was more to the legislative context of 1982 than just the Canadian experience, which would have inevitably placed the idea of including a right to bargain or a right to strike in the constitution within the contemplation of the drafters of the Charter. The same international context that the majority relied on in SFL to justify reading these kinds of rights into s. 2(d) has been pointed to, and I maintain properly so, to make the opposite argument: if other nations' constitutions which were part of the existing legal landscape when the Charter was made law in 1982 constitutionalized a right to collective 
bargaining or a right to strike in explicit terms, the omission to do the same in our constitution should be understood to have been deliberate.

Again, Justice McIntyre was alive to this international legislative context back in 1987, in the Alberta Reference case:

Specific reference to the right to strike appears in the constitutions of France (in the preamble of the Constitution of the Vth Republic of 1958) and Italy (Article 40). Further, in Japan (Article 28) the rights of trade unions are specifically guaranteed. The framers of the Constitution must be presumed to have been aware of these constitutional provisions. The omission of similar provisions in the Charter, taken with the fact that the overwhelming preoccupation of the Charter is with individual, political, and democratic rights with conspicuous inattention to economic and property rights, speaks strongly against any implication of a right to strike. Accordingly, if s. 2(d) is read in the context of the whole Charter, it cannot, in my opinion, support an interpretation of freedom of association which could include a right to strike. ${ }^{18}$

Justices Rothstein and Wagner picked up the same point in their jointly written dissent in SFL:

158 The majority notes that the right to strike is contained in a number of foreign constitutions, as well as in the European Convention on Human Rights, 213 U.N.T.S. 221 (1950), and the European Social Charter (E.T.S. No. 35, 1961, revised E.T.S. No. 163, 1996) (paras. 71 and 74). However, the express inclusion of the right to strike in domestic constitutions and charters other than our own has little relevance to this Court's interpretation of 'freedom of association' under s. 2(d). If anything, the absence of an express right to strike in the Charter - which was enacted subsequent to many of the constitutions cited by the majority - indicates Parliament and the provincial legislatures' intention to exclude such a right ... ${ }^{19}$

Constitutional enactments, to fulfill their purposes, are to receive generous and liberal interpretations. However, this is not the same as reading them ideologically or politically, or in a fashion that comes unanchored from the words used in these legal instruments. In Justice Rothstein's dissent in MPAO he observed:

The judicial branch must not exercise its great constitutional power to make rulings that are not firmly rooted in the text, context, and purpose of Canadian constitutional law. While a purposive approach to Charter interpretation has long been accepted, in the words of Dickson J. (as he then was) in R. v. Big M Drug Mart Ltd., [1985] 1 S.C.R. 295, at p. 344, 'it is important not to overshoot the actual purpose of the right or freedom in question'. ${ }^{20}$

And further, at para. 174: "[t]he interpretation of a Charter right must be principled and must not be so divorced from the text of the provision as to depart from the foundation of the right." ${ }^{21}$

Over the nearly three decades that separate the old labour trilogy from the new, I maintain that the Supreme Court's reasoning has become detached from the words of section 2(d) of the Charter, and from its original, straightforwardly important and broadly applicable purpose, within a framework of fundamental freedoms conferred on all. In an incremental, though hardly linear, way since 1987 the Court has transmuted s. 2(d) into a narrower, more partisan social policy tool that it has mainly used to address what it believes to be power imbalances in labour relations.

\section{Inconsistent outcomes}

At the outset of the majority decision in SFL, Justice Abella described the course of the Court's jurisprudence on the meaning of freedom of association in the labour relations sphere in the following way:

In the Alberta Reference (Reference re Public Service Employee Relations Act (Alta.), [1987] 1 S.C.R. 313), this Court held that the freedom of association guaranteed under s. 2(d) of the Canadian Charter of Rights and Freedoms did not protect the right to collective bargaining or to strike. Twenty years later, in Health Services and Support - Facilities Subsector Bargaining Assn. v. British Columbia, [2007] 2 S.C.R. 391, this Court held that s. 2(d) protects the right of employees to engage in a meaningful 
process of collective bargaining. The rights were further enlarged in Ontario (Attorney General) v. Fraser, [2011] 2 S.C.R. 3, where the Court accepted that a meaningful process includes employees' rights to join together to pursue workplace goals, to make collective representations to the employer, and to have those representations considered in good faith, including having a means of recourse should the employer not bargain in good faith. And, most recently, in Mounted Police Association of Ontario v. Canada (Attorney General), [2015] 1 S.C.R. 3, the Court recognized that a process of collective bargaining could not be meaningful if employees lacked the independence and choice to determine and pursue their collective interests. Clearly the arc bends increasingly towards workplace justice. ${ }^{22}$

The suggestion that the path of the Court's reasoning from the first labour trilogy to the most recent one has been a logical progression seems at odds with reality, at least as experienced by labour relations practitioners and lower courts. In particular, the characterization by the Court of Fraser as having plotted another consistent, predictable point along "the arc bend[ing] increasingly towards workplace justice", and as having "further enlarged" rights of employees to a meaningful process of collective bargaining, must have come as quite a surprise to agricultural workers in Ontario.

In their dissent in SFL Justices Rothstein and Wagner took umbrage with the majority's reinterpretation of Fraser. In my view, they were fully justified in so doing. They said, at paras 147-48:

... a finding that there is a constitutional right to strike (or to an alternative statutory dispute resolution process), is an express contradiction of this Court's ruling in Fraser that s. 2(d) of the Charter does not require a statutory dispute resolution process (para. 41). While s. 2(d) jurisprudence has evolved since 1987, such changes cannot be used to justify contradicting the decisions that brought about these very same changes.

148 Even more puzzling, the majority claims that the Court affirmed in Fraser that a meaningful process under s. $2(d)$ of the
Charter must include some 'means of recourse should the employer not bargain in good faith' (para. 29). They do so despite explicit language to the contrary in that case (see Fraser, at para. 41). In misinterpreting the content of Fraser, our colleagues overrule that decision without acknowledging that they are doing so. ${ }^{23}$

Comparing the outcomes in Fraser and SFL is a baffling exercise. That the minimalist provisions of Ontario's (exaggeratedly named) Agricultural Employees Protection Act ${ }^{24}$ withstood constitutional scrutiny, while the much more robust and elaborately balanced Public Service Essential Services $A c t^{25}$ in Saskatchewan did not, defies a logical explanation short of acknowledging that the Court decided to change the legal test it adopted in Fraser and create a new one.

It is no coincidence that in all three of the cases that ended up forming the new labour trilogy in the Supreme Court, the decisions of trial-level judges had been reversed by appellate courts, only to be reversed again in two out of the three cases by the Supreme Court of Canada. It is evident that in the period since Health Services, then following Fraser, and now most recently with the trio of judgments in 2015 , lower courts have been struggling mightily to "read the tea leaves" that the Supreme Court has been leaving behind in its ongoing re-envisioning of the scope of the constitutional freedom of association in labour relations settings.

In the course of rendering its decisions in the new labour trilogy the Supreme Court also explicitly overruled two of its own decisions; in $M P A O$, the majority decided that the Court's contrary decision in Delisle $v$ Canada (Deputy $A G),{ }^{26}$ which dealt with a substantially similar issue, could no longer stand. ${ }^{27}$ In $S F L$, the Court finished the task of overruling the 1987 Alberta Reference case that it had begun in Health Services. And to these two reversals of Supreme Court precedents can be added the de facto departure in SFL from the Court's reasoning in Fraser.

The overturning of precedents and the surprising course changes in the evolution of the Supreme Court's jurisprudence in this area are 
bound to have a destabilizing effect on the law, and more importantly on the regulation of collective labour relations. Governments across the country, including Alberta's, are now actively re-assessing the constitutional validity of their labour legislation in light of the new labour trilogy. Significant changes are in store.

The level of uncertainty about how the new law pronounced by the Supreme Court will be applied, about what government actors will be permitted to do to regulate labour relations from day to day, sector to sector, situation to situation, and dispute to dispute is likely to remain high into the future. One of the effects of the Supreme Court's decisions to recognize rights to collective bargaining and to strike as protected Charter rights is that state efforts to moderate or balance the exercise of these rights will be presumptively unconstitutional unless a government can convince a court that its legislative intervention is justified under a section 1 analysis. There is the clear prospect that judges, many of whom will have little practical experience or expertise in labour relations, will be increasingly called upon to decide how to find the right balance in complex, sensitive labour relations matters that engage important public and private interests. This seems a recipe for trouble, and brings me to my third criticism of the new labour trilogy.

\section{The roles of courts and legislatures}

One of the fundamental precepts of our democratic form of government is the separation of roles between legislatures and the judiciary. I agree with Justice Rothstein's assessment that the new labour trilogy has confused these roles when it comes to regulating labour relations. His dissent in MPAO contains this admonition:

159 In a constitutional democracy, the judicial branch of government is entrusted to rule on whether laws enacted by the legislature pass constitutional muster. But this Court's rulings are not subject to review. Its rulings are binding on the legislative branch, unless that branch invokes the rarely resortedto s. 33 of the Canadian Charter of Rights and Freedoms to provide that its legislation will operate notwithstanding breaches of certain constitutional rights. This means that constitutional decisions of this Court have the power to freeze matters in time and restrict Parliament's ability to change course in the future, where facts and policy imperatives may suggest or require a different approach.

160 It is fundamental, therefore, that the judicial and legislative branches of government have respect for the role and responsibility of the other. The legislative branch must respect the decisions of the courts and comply with them. Courts must equally respect the role of the democratically elected legislature and its policy choices. ...

161 Courts must be especially cautious when dealing with questions of socio-economic policy. Just as the government and legislature must respect the courts' expertise as judicial bodies, so too must courts appreciate that they are not best placed to make determinations as to which specific social or economic policy choice is most appropriate. The evaluation and implementation of social and economic policy require flexibility and fine-tuning. Courts should not expand Charter rights in such a way as to prevent governments from responding to new information or changing social and economic conditions.

162 In my respectful opinion, the majority has departed from these core principles of constitutional law in this case. I am compelled to dissent. The courts must respect that concerns such as maintaining 'the balance between employees and employer' and attaining 'equilibrium' in labour relations (see majority reasons, at paras. 72 and 82) fall within the proper role and expertise of governments and legislatures, not the judiciary. ${ }^{28}$

There is a long history of the Supreme Court recognizing that labour relations law is a complex and distinctive area, and that courts should defer to legislators, specialized tribunals and practitioners to define policy, make laws and administer them in this field. While this recognition preceded the old labour trilogy of 1987, the Court was certainly conscious of the proper division of responsibilities when it decided those cases. As Justice Le Dain observed, writing for three of the four judges in the majority in the Alberta Reference case: 
The rights for which constitutional protection is sought -- the modern rights to bargain collectively and to strike, involving correlative duties or obligations resting on an employer - are not fundamental rights or freedoms. They are the creation of legislation, involving a balance of competing interests in a field which has been recognized by the courts as requiring a specialized expertise. It is surprising that in an area in which this Court has affirmed a principle of judicial restraint in the review of administrative action we should be considering the substitution of our judgment for that of the Legislature by constitutionalizing in general and abstract terms rights which the Legislature has found it necessary to define and qualify in various ways according to the particular field of labour relations involved. The resulting necessity of applying s. 1 of the Charter to a review of particular legislation in this field demonstrates in my respectful opinion the extent to which the Court becomes involved in a review of legislative policy for which it is really not fitted. ${ }^{29}$

This same sentiment was expressed in the dissent of Justices Rothstein and Wagner in SFL, at para 105; they even drew support from a previous ruling written by Chief Justice McLachlin and Justice LeBel, who later ended up with the majority in SFL deciding in favour of the Court "knowing better" and striking down the impugned legislative action:

105 McLachlin C.J. and LeBel J., writing for a unanimous Court in R.W.D.S.U., Local 558 v. Pepsi-Cola Canada Beverages (West) Ltd., 2002 SCC 8, [2002] 1 S.C.R. 156, cautioned that

[j]udging the appropriate balance between employers and unions is a delicate and essentially political matter. Where the balance is struck may vary with the labour climates from region to region. This is the sort of question better dealt with by legislatures than courts. Labour relations is a complex and changing field, and courts should be reluctant to put forward simplistic dictums. [para. 85]

Thirteen years later, the majority in this case ignores this sage warning in reaching its conclusion. Our colleagues have taken it upon themselves to determine the appropriate balance between employers and unions', despite the fact that this balance is not any less delicate or political today than it was in 2002. In our respectful view, the majority is wrong to intrude into the policy development role of elected legislators by constitutionalizing the right to strike. ${ }^{30}$

There is an undeniably vital role for the courts to play interpreting constitutional laws in a purposive manner to safeguard fundamental liberties of citizens against improper or misguided state action. There is an equally important role for elected governments to play to set and implement socio-economic policy, and to change these policies and their implementation to respond to changing societal circumstances. I fear that in the new labour trilogy the Supreme Court has opted to descend into the policy arena, to set parameters for all future legislative action to advance its own formulation of what it calls "workplace justice". Constitutionalizing the Supreme Court's current vision of the "appropriate balance" in labour relations also means that an ongoing role will be reserved to judges to set labour relations policy and "strike" that elusive balance into the future. We can only hope that with practice they become more predictable, more consistent and better at it.

\section{Endnotes}

* Partner, Neuman Thompson

1 Part I of the Constitution Act, 1982, being Schedule B to the Canada Act 1982(UK), 1982, c 11 [Charter].

22015 SCC 1, [2015] 1 SCR 3 [MPAO].

32015 SCC 2, [2015] 1 SCR 125 [Meredith].

42015 SCC 4, [2015] 1 SCR 245 [SFL].

5 [1987] 1 SCR 313 [Alberta Reference].

6 [1987] 1 SCR 424 [Public Service Alliance].

7 [1987] 1 SCR 460.

82007 SCC 27, [2007] 2 SCR 391 [Health Services].

92011 SCC 20, [2011] 2 SCR 3 [Fraser].

10 Dunmore v Ontario (AG), 2001 SCC 94, [2001] 3 SCR 1016.

11 Fraser, supra note 8.

12 MPAO, supra note 2 at paras 81-83.

13 Meredith, supra note 3 at paras 25-30.

14 Public Service Alliance, supra note 6. 
15 SFL, supra note 4.

16 Ibid at paras 2-3.

17 Alberta Reference, supra note 5.

18 Ibid at 413.

19 SFL, supra note 4 at para 158.

20 MPAO, supra note 2 at para 160.

21 Ibid.

22 SFL, supra note 4 at para 1.
23 Ibid.

24 SO 2002, c 16.

25 SS 2008, c P-42.2.

26 [1999] 2 SCR 989.

27 MPAO, supra note 2 at paras 124-27.

28 Ibid at paras 159-62.

29 Alberta Reference, supra note 5 at 391-92.

30 SFL, supra note 4 at para 105. 